\title{
Studies on Spiraea $x$ vanhouteii Growth Under the Influence of Sun Exposure
}

\author{
Raluca TOMA ${ }^{1 *}$, Dumitru ZAHARIA ${ }^{2)}$ \\ 1) Faculty of Horticulture, University of Agricultural Sciences and Veterinary Medicine Cluj-Napoca, \\ Calea Mănăştur 3-5, 400372, Cluj-Napoca, Romania \\ ${ }^{*}$ Corresponding author, e-mail: ralucatoma17@yahoo.com
}

Bulletin UASVM Horticulture 71(2) / 2014

Print ISSN 1843-5254, Electronic ISSN 1843-5394

DOI:10.15835/buasvmcn-hort:10408

\begin{abstract}
The purpose of this study is to show the influence of built environment over plant development in urban areas. It is well known that environmental factors are influenced by the built environment and human activities within the cities. Built environment affects especially the temperature of ambient due to the interaction between solar radiations, the materials from which buildings and streets are made of, as well as the urban design. Direct sun exposure and its direct effects are most affected by urban tissue configuration within the area. Observations were made over phenological evolution of Spiraea $x$ vanhouttei species during four years, in Cluj-Napoca, Romania. The study area was selected because the environmental conditions (precipitations, wind, pollution etc.) that can affect the development of hedges are identical, except for sun exposure. The shading period, established with the sun-study tool of ArchiCAD, to which the plants were exposed, differ on the north and south part of the study area respectively, and thus generated differences regarding the phenological stages of leaf development and flowering.
\end{abstract}

Keywords: sun exposure, solar radiation, phenological stages, urban environment.

\section{INTRODUCTION}

Phenology is a discipline that observes and studies the evolution of plant development and animal activities which have a cyclic character and coincide with the seasonal development generated by the sun annual cycle, especially in temperate climates (Schwartz, 2003). The connection between sun and vegetation is undeniable. Plant phenology, especially during spring season, is affected by temperature and photoperiod (Beverly, 2007; Polgar and Primack, 2011).

Researchers lately noted that there are differences in plant phenology in urban areas as compared to rural areas (Roetzer et al., 2000; Kaesha and Jianguo $\mathrm{Wu}, 2006)$. Those differences are noticeable in the tendency to leaf out and blossom earlier in urban areas. This phenomenon is due to the fact that the urban environment has distinct characteristics as compared to rural surroundings, which are closer to the natural landscape, opposite to the built environment's that influence the urban climate. The materials and shape of buildings and of urban surfaces, as well as urban design (form, height and placement) impinge on the urban microclimate especially over the hygrothermal aspects (Dessì, 2010).

Urban microclimate is influenced by solar radiation, but also by terrestrial radiation. Solar radiation that reaches the earth is mostly within the visible spectrum and has two components: direct solar radiation and diffuse sky radiation. Direct solar radiation is the one that has an important impact over the energy balance of an area, especially on a sunny day. On the other hand, terrestrial radiation is the one which is reflected by, or absorbed and later reemitted, by the objects and surfaces of the urban environment. Terrestrial radiation is in the infrared spectrum and affects the microclimate (Scudo and Ochoa de la Torre, 2006).

The type of materials used for buildings influences the energy balance through features such as albedo, emissivity, specific heat and thermal diffusivity. These features are specific 
for each material and are influenced by direct sun exposure, which affects the amount of heat accumulated by surrounding objects, and thus thermal radiation in the area, which in turn influences the ambient temperature (Dessì, 2010).

The objective of this study is to show the influence of built environment over plant phenology. It aims to emphasise the importance of the urban microclimate over the ornamental vegetation phenology.

\section{MATERIALS AND METHODS}

Observations were conducted over a period of four years between 2011 and 2014, in ClujNapoca. During this interval, emphasis was made on the phenological development in springtime of Spiraea $x$ vanhouttei hedges located along Donath Street. This location was chosen because of hedge vegetation that was exposed to the same environmental conditions (pollution, wind, precipitation, etc.) except the periods of direct sun exposure, which differs along the two sides of Donath Street. The differences of direct sun exposure are due to the west - east street axis orientation and the buildings' height (over $14 \mathrm{~m}$ ), arranged along both sides of the street.

Because leaf out and flowering are two phenological stages sensitive to environmental conditions like temperature, photoperiod and light intensity, conditions that are directly connected to solar radiation, their development has been monitored.

The BBCH (Biologische Bundesanstalt, Bundessortenamt and Chemical industry) code was used to establish the phenological stages (Hack et al., 2001; Finn et al., 2007). Phenological stages were considered as followed: stage 11 is the leaf out moment when the first leaves begin to unfold, stage 61 -is the beginning of flowering and represents the moment when $10 \%$ of the flowers open and stage 69 - end of flowering represents the moment when all flowers have fallen or faded out.

Daytime duration (number of hours from sunrise to sunset) for Cluj-Napoca was calculated using the online calculator of "Amiral Vasile Urseanu" Astronomical Observatory in București (Tab. 1)

ArchiCAD was used to determine sunlight exposure of the studied area. Aided by the applications of this program, the built environment was virtually constructed and later used for a sun study calculation. The sun study was made for the period between March the 1st and June the 1st which corresponds to the period from leaf out to flowering of Spiraea $x$ vanhouttei species. The geographical coordinates of Cluj-Napoca were introduced in the program database: $46^{\circ} 46^{\prime}$ North, $23^{\circ} 36^{\prime}$ East, respectively +2 h GMT. The program generated realistic building shadows during daytime and thus allowed to establish the number of hours of direct sunlight exposure and those of shade (Fig. 1).

The obtained results were correlated with the starting dates of the three phenological stages that were established before.

Tab. 1. Length of day light during the spring season in Cluj-Napoca

\begin{tabular}{|c|c|c|c|c|c|c|c|c|c|c|c|c|c|c|}
\hline & \multicolumn{14}{|c|}{ Date } \\
\hline & 1.03 & 7.03 & 14.03 & 21.03 & 28.03 & 4.04 & 11.04 & 18.04 & 25.04 & 2.05 & 9.05 & 16.05 & 23.05 & 30.05 \\
\hline $\begin{array}{l}\text { Sun } \\
\text { rising }\end{array}$ & 7:06 & $6: 55$ & $6: 41$ & $6: 27$ & $6: 13$ & $\begin{array}{l}\text { 7:00 } \\
\text { DST }\end{array}$ & 6:46 DST & $\begin{array}{l}6: 33 \\
\text { DST }\end{array}$ & $\begin{array}{l}\text { 6:21 } \\
\text { DST }\end{array}$ & $\begin{array}{l}\text { 6:09 } \\
\text { DST }\end{array}$ & $\begin{array}{l}5: 59 \\
\text { DST }\end{array}$ & $\begin{array}{l}5: 50 \\
\text { DST }\end{array}$ & $\begin{array}{l}5: 43 \\
\text { DST }\end{array}$ & $\begin{array}{l}5: 37 \\
\text { DST }\end{array}$ \\
\hline Sunset & $18: 11$ & $18: 20$ & $18: 30$ & $18: 39$ & $18: 49$ & $\begin{array}{c}19: 59 \\
\text { DST }\end{array}$ & 20:08DST & $\begin{array}{c}20: 18 \\
\text { DST }\end{array}$ & $\begin{array}{c}20: 27 \\
\text { DST }\end{array}$ & $\begin{array}{c}20: 37 \\
\text { DST }\end{array}$ & $\begin{array}{c}20: 46 \\
\text { DST }\end{array}$ & $\begin{array}{c}20: 55 \\
\text { DST }\end{array}$ & $\begin{array}{c}21: 03 \\
\text { DST }\end{array}$ & $\begin{array}{c}21: 10 \\
\text { DST }\end{array}$ \\
\hline $\begin{array}{c}\text { Daylight } \\
\text { Hours }\end{array}$ & $11 \mathrm{~h} 5^{\prime}$ & $\begin{array}{l}11 \mathrm{~h} \\
25^{\prime}\end{array}$ & $\begin{array}{l}11 \mathrm{~h} \\
51^{\prime}\end{array}$ & $\begin{array}{l}12 \mathrm{~h} \\
12^{\prime}\end{array}$ & $\begin{array}{l}12 \mathrm{~h} \\
36^{\prime}\end{array}$ & $\begin{array}{l}12 \mathrm{~h} \\
59^{\prime}\end{array}$ & $13 \mathrm{~h} 32^{\prime}$ & $\begin{array}{l}13 \mathrm{~h} \\
46^{\prime}\end{array}$ & $14 \mathrm{~h} 6^{\prime}$ & $\begin{array}{l}14 \mathrm{~h} \\
28^{\prime}\end{array}$ & $\begin{array}{l}14 \mathrm{~h} \\
47^{\prime}\end{array}$ & $15 \mathrm{~h} 5^{\prime}$ & $\begin{array}{l}15 \mathrm{~h} \\
20^{\prime}\end{array}$ & $\begin{array}{l}15 \mathrm{~h} \\
33^{\prime}\end{array}$ \\
\hline
\end{tabular}

NOTE: DST (Daylight Saving Time) represents the summer time included in the calculations 


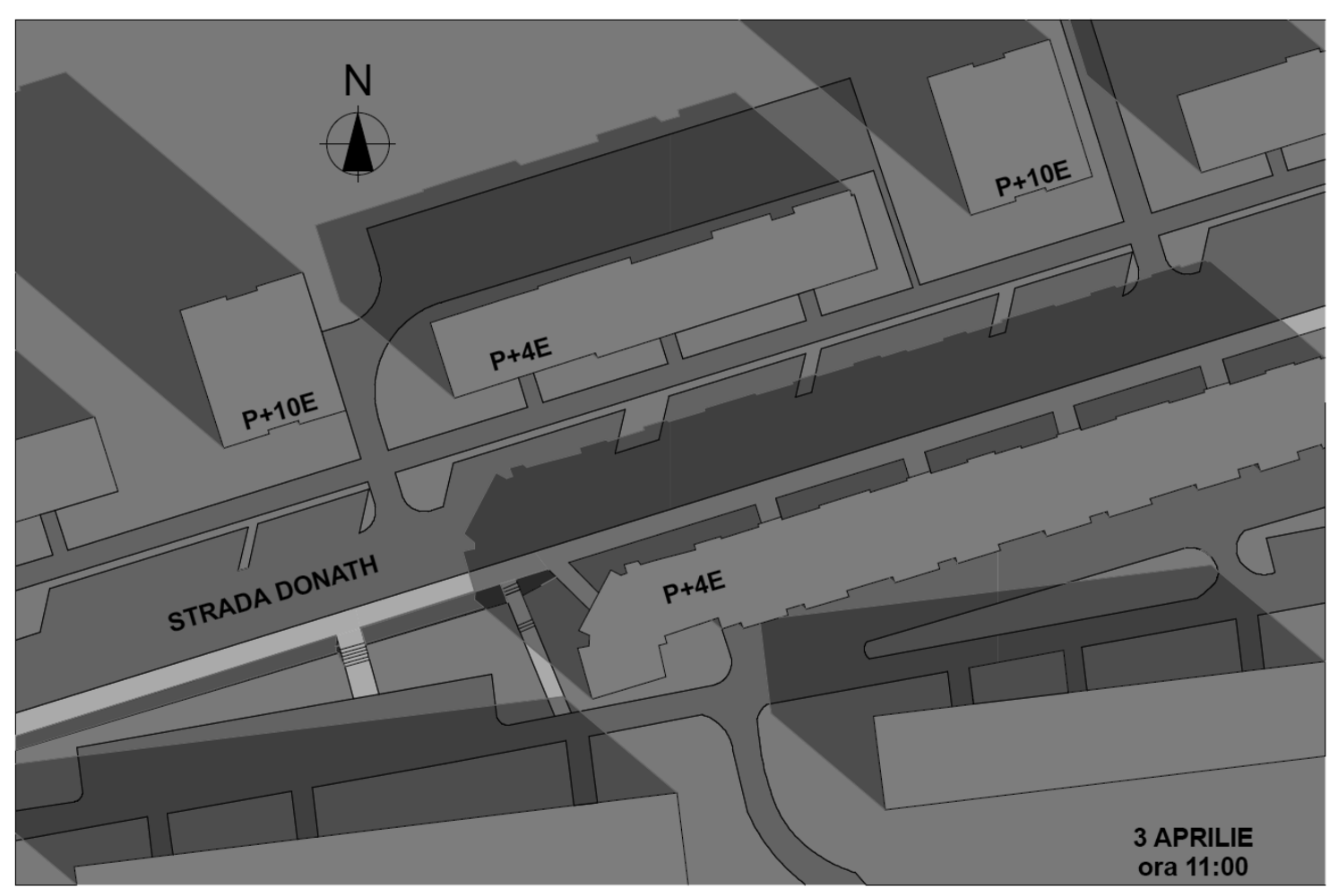

Fig. 1. Sun study excerpt on Donath Street

Tab. 2. Length of sun exposure on both sides of Donath Street

\begin{tabular}{|c|c|c|c|c|c|c|c|c|c|c|c|c|c|c|}
\hline \multicolumn{15}{|c|}{ Date } \\
\hline 1.03 & 7.03 & 14.03 & 21.03 & 28.03 & 4.04 & 11.04 & 18.04 & 25.04 & 2.05 & 9.05 & 16.05 & 23.05 & 30.05 & 06.06 \\
\hline \multicolumn{15}{|c|}{ Length of sun exposure on the north side of Donath Street } \\
\hline $6 \mathrm{~h}$ & $7 \mathrm{~h}$ & $7 \mathrm{~h}$ & $8 \mathrm{~h}$ & & $10 \mathrm{~h}$ & $10 \mathrm{~h}$ & $11 \mathrm{~h}$ & $11 \mathrm{~h}$ & $10 \mathrm{~h}$ & $10 \mathrm{~h}$ & $10 \mathrm{~h}$ & $10 \mathrm{~h}$ & $10 \mathrm{~h}$ & $10 \mathrm{~h}$ \\
\hline $30^{\prime}$ & $15^{\prime}$ & $45^{\prime}$ & $20^{\prime}$ & $9 \mathrm{~h}$ & $30^{\prime}$ & $50^{\prime}$ & $12^{\prime}$ & $15^{\prime}$ & $50^{\prime}$ & $40^{\prime}$ & $30^{\prime}$ & $20^{\prime}$ & $15^{\prime}$ & $10^{\prime}$ \\
\hline \multicolumn{15}{|c|}{ Length of sun exposure on the south side of Donath Street } \\
\hline $1 \mathrm{~h}$ & $1 \mathrm{~h}$ & $2 \mathrm{~h}$ & $2 \mathrm{~h}$ & & $2 \mathrm{~h}$ & $2 \mathrm{~h}$ & $2 \mathrm{~h}$ & $2 \mathrm{~h}$ & $3 \mathrm{~h}$ & $3 \mathrm{~h}$ & $3 \mathrm{~h}$ & $3 \mathrm{~h}$ & $2 \mathrm{~h}$ & $2 \mathrm{~h}$ \\
\hline $11^{\prime}$ & $50^{\prime}$ & $2 \mathrm{~h}$ & $10^{\prime}$ & $2 \mathrm{~h}$ & $15^{\prime}$ & $35^{\prime}$ & $45^{\prime}$ & $50^{\prime}$ & $10^{\prime}$ & $20^{\prime}$ & $20^{\prime}$ & $30^{\prime}$ & $45^{\prime}$ & $45^{\prime}$ \\
\hline
\end{tabular}

\section{RESULTS AND DISCUSSION}

The sun study showed that plants on the south side are exposed less than 3.5 hours to direct sunlight, whereas plants situated on the north side were exposed to sunlight for at least 6 hours a day in March, and as much as 11 hours a day in the second half of April (Tab. 2).

The starting point of leaf out and the beginning of flowering and its duration were determined during four seasons. Calendar days were used to assess the starting point of each phenological stage. DOY (Day Of Year) was used to assess the duration of phenological stages (Tab. 3).
Analysing data of the beginning of phenological stages during the four year period shows that are significant differences between the two sides of the street.

Leaf out starting point - stage 11 - was happening later on the south side of the street. The average difference between the times until leaf unfolding was by 7 day earlier on the north side compared to the south side of the street.

The beginning of flowering - stage 61 - took place later on the south side of the street, on average by 5.5 days from the onset on the north side. 
Tab. 3. Beginning and length of phenological phases in Donath Street for Spiraea $x$ vanhouttei

\begin{tabular}{|c|c|c|c|c|c|c|c|c|}
\hline Year & $\begin{array}{c}\text { Donath } \\
\text { street } \\
\text { side } \\
\end{array}$ & $\begin{array}{c}\text { Beginning } \\
\text { of leaf } \\
\text { development }\end{array}$ & $\begin{array}{c}\text { Time } \\
\text { until leaf } \\
\text { unfolding }\end{array}$ & $\begin{array}{l}\text { Beginning } \\
\text { of flowering }\end{array}$ & $\begin{array}{l}\text { Time until } \\
\text { flowering }\end{array}$ & $\begin{array}{l}\text { Ending } \\
\text { of flowering }\end{array}$ & $\begin{array}{l}\text { Time until } \\
\text { ending of } \\
\text { flowering }\end{array}$ & $\begin{array}{c}\text { Flowering } \\
\text { length }\end{array}$ \\
\hline & & BBCH 11 & & BBCH 61 & & BBCH 69 & & \\
\hline & & calendar day & DOY & $\begin{array}{c}\text { calendar } \\
\text { day }\end{array}$ & DOY & $\begin{array}{c}\text { calendar } \\
\text { day }\end{array}$ & DOY & days \\
\hline \multirow{2}{*}{2011} & North & 30.03 & 89 & 12.05 & 132 & 23.05 & 143 & 11 \\
\hline & South & 06.04 & 96 & 18.05 & 138 & 02.06 & 153 & 15 \\
\hline \multirow{2}{*}{2012} & North & 31.03 & 91 & 06.05 & 127 & 18.05 & 139 & 12 \\
\hline & South & 07.04 & 98 & 10.05 & 131 & 26.05 & 147 & 16 \\
\hline \multirow{2}{*}{2013} & North & 02.04 & 92 & 02.05 & 122 & 16.05 & 136 & 14 \\
\hline & South & 08.04 & 99 & 09.05 & 129 & 27.05 & 147 & 18 \\
\hline \multirow{2}{*}{2014} & North & 12.03 & 71 & 27.04 & 117 & 17.05 & 137 & 20 \\
\hline & South & 19.03 & 78 & 02.05 & 122 & 26.05 & 146 & 24 \\
\hline
\end{tabular}
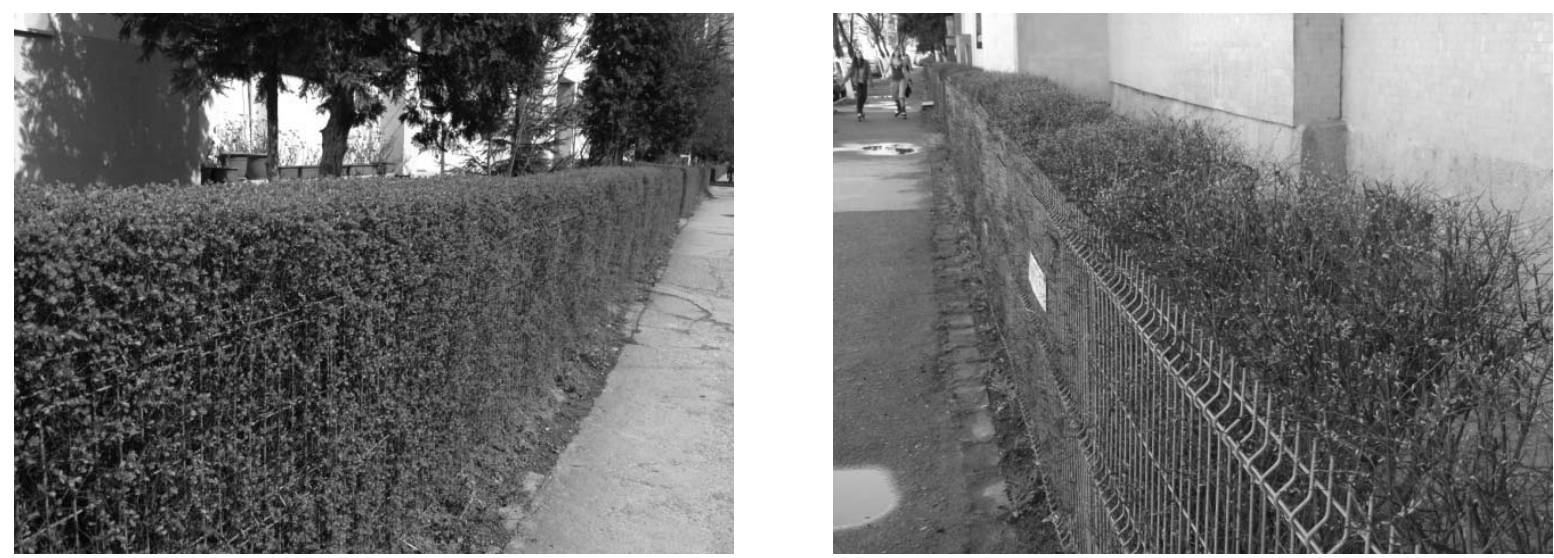

Fig. 2. Images of the hedges on Donath Street, the north side on the left and the south side on the right on April 3rd, 2011
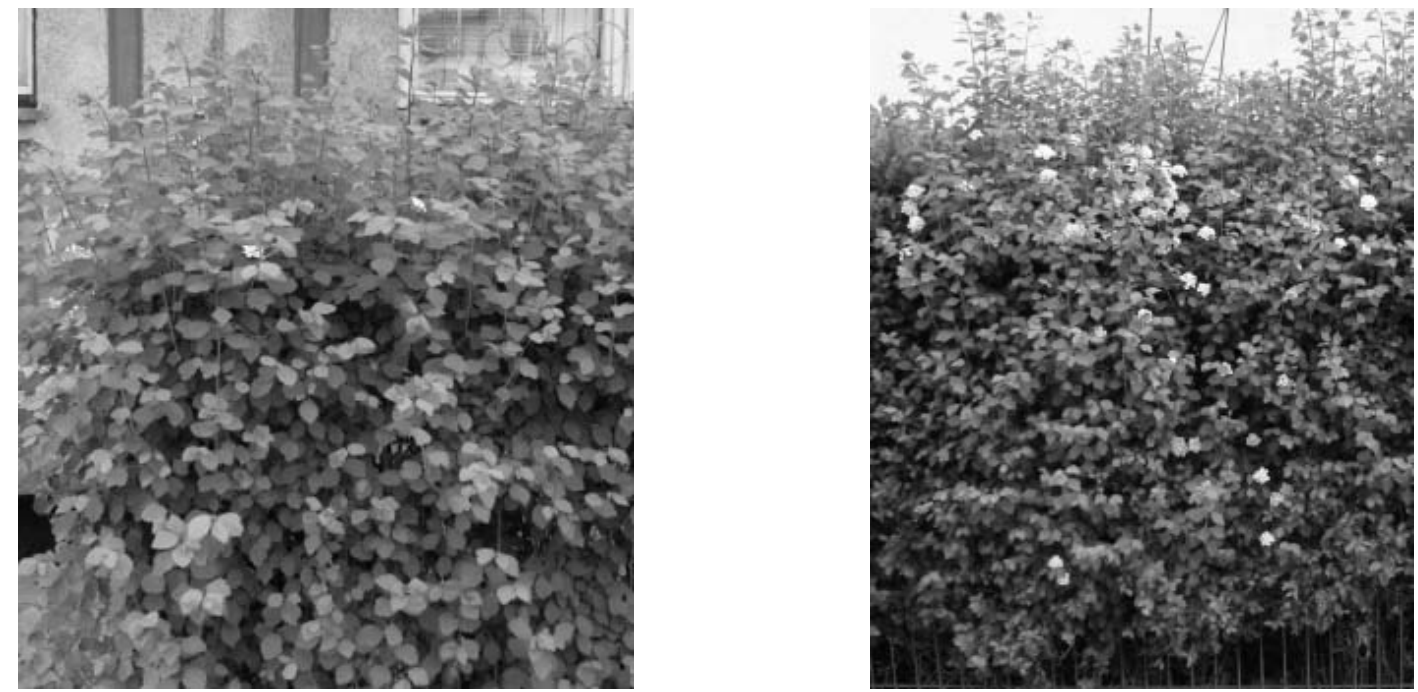

Fig. 3. Images of the hedges on Donath Street, the south side on the left and the north side on the right on May 10th, 2012 
Also the end of flowering - stage 69 - occurs on average 9.5 days later on the south side of the street than on the north side.

The flowering period is longer on the south side of the street on average by 4 days than on the north side.

Differences of phenological evolution are visible both during leaf out and during flowering, but because the hedges are pruned each year to maintain the geometrical shape, the effect is more obvious during the leaf unfolding (Fig. 2) than during the blossoming (Fig. 3).

Over the years it became well known that urbanization has a very important impact on climate conditions and the urban heat island phenomenon is well known. Especially the thermal properties of building materials increase the quantity of solar radiation accumulated in the urban areas (Gartland, 2008). Numerous studies and research has been conducted to mitigate the urban microclimate conditions and vegetation is considered as a powerful instrument in the process (McPherson, 1992; Scudo and Ochoa de la Torre, 2006; Dessì, 2010). On the other hand studies on the impact of built environment over the urban vegetation, especially the ornamental shrubs haven't been found even though is well known that temperature and light affect plant development (Zaharia et al., 2008).

\section{CONCLUSIONS}

Sunlight affects phenological development of Spiraea $x$ vanhouttei species. Plants that have been exposed for a longer time to direct sunlight begin to leaf out and to blossom earlier than those that are on direct sun light for a shorter period. Sun exposure affects also the de duration of flowering and its end, as the flowering period is longer on south side.

The comprehension of the manner in which plants develop under the influence of shading can help landscape architects to choose adequate species to the given location during project elaboration. Designing hedges made with vegetation sensitive to sunlight exposure along urban areas can generate discrepancies between side images, because of the differences that occur between phenological stages. Those dissimilarities, especially during spring time, offer completely different images than the intention of landscape architects, who might have imagined symmetry and uniformity as specific to a geometric organized space when using the same species on the hedges.

\section{REFERENCES}

1. Beverly G (2007). Understanding flowers and flowering. An integrated approach, Oxford University Press, New York.

2. Dessì V (2010). Progettare il comfort urbano. Soluzioni per un' integrazione tra società e territorio, Gruppo Editoriale Esselibri-Simone, Napoli.

3. Finn GA, Straszewski AE, Peterson V (2007). A general growth stage key for describing trees and woody plants, Annals of Applied Biology 151:127-13.

4. Gartland L(2008). Heat Islands. Understanding and Mitigationg Heat in Urban Areas, Earthscan, London

5. Hack H, Bleiholder H, Buhr L, Meier U, Schnock-Fricke U, Weber E, Witzenberger A (2001). The extended BBCHscale, "Growth stages of mono-and dicotyledonous plants. BBCH Monograph", Federal Biological Research Centre for Agriculture and Forestry, p. 6-13.

6. Kaesha N, Jianguo W (2006). Effects of urbanization on plant flowering phenology: A review, Urban Ecosystems 9:243-257.

7. McPherson EG (1992). Accounting for benefits and costs of urban green space, Landscape and urban Planning 22:41-51

8. Polgar C, Primack RB (2011). Leaf-out phenology of temperate woody plants from trees to ecosystems, New Phytologist 191:926-941

9. Roetzer T, Wittenzeller M, Heackel H, Nekovar J (2000). Phenology in central Europe - differences and trends of spring phenophases in urban and rural areas, International Journal of Biometeorology 44:60-66.

10. Scudo G, Ochoa de la Torre JM (2006). Spazi verdi urbani. La vegetazione come strumento di progetto per il comfort ambientale negli spazi abitati, Gruppo Editoriale EsselibriSimone, Napoli.

11. Schwartz MD (2003). Phenology. An integrative Environmental Science, Kluwer Academic Publishers, Dordrecht.

12. Zaharia D, Dumitraș A, Zaharaia A (2008). Wooden ornamental species, Todesco, Cluj-Napoca 